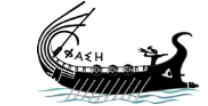

journal.phaselis.org
PHAS LLIS

Issue IV (2018)
Disiplinlerarası Akdeniz Araştırmaları Dergisi

Journal of Interdisciplinary Mediterranean Studies

\title{
Kıуı Karia Arkaik Dönem Seramiği: Miletos Tipinde Ticari Amphoralar ve Bölgesel Amphora Üretimi ve Dağılımı Üzerine Bazı Sorular ve Ön Görüşler
}

\author{
Archaic Pottery of Coastal Caria: Milesian Type Trade \\ Amphorae, Some Questions and Preliminary Observations on \\ the Production and the Distribution of Regional Amphora
}

\section{Bekir ÖZER}

open 2 access journals

The entire contents of this journal, Phaselis: Journal of Interdisciplinary Mediterranean Studies, is open to users and it is an 'open access' journal. Users are able to read the full texts, to download, to copy, print and distribute without obtaining the permission of the editor and author(s). However, all references to the articles published in the e-journal Phaselis are to indicate through reference the source of the citation from this journal.

Phaselis: Journal of Interdisciplinary Mediterranean Studies is a peer-reviewed journal and the articles which have had their peer reviewing process completed will be published on the web-site (journal.phaselis.org) in the year of the journal's issue (e.g. Issue III: JanuaryDecember 2017). At the end of December 2016 the year's issue is completed and Volume IV: January-December 2018 will begin.

Responsibility for the articles published in this journal remains with the authors.

Citation B. Özer, "Kıyı Karia Arkaik Dönem Seramiği: Miletos Tipinde Ticari Amphoralar ve Bölgesel Amphora Üretimi ve Dağılımı Üzerine Bazı Sorular ve Ön Görüşler”. Phaselis IV (2018) 89117. http://dx.doi.org/10.18367/Pha.18007

Received Date: 12.03.2018 | Acceptance Date: 04.04.2018

Online Publication Date: 25.04.2018

Editing Phaselis Research Project www.phaselis.org 


\title{
Kıyı Karia Arkaik Dönem Seramiği: Miletos Tipinde Ticari Amphoralar ve Bölgesel Amphora Üretimi ve Dağılımı Üzerine Bazı Sorular ve Ön Görüşler
}

\author{
Archaic Pottery of Coastal Caria: Milesian Type Trade Amphorae, Some Questions and \\ Preliminary Observations on the Production and the Distribution of Regional Amphora
}

\author{
Bekir ÖZER*
}

Öz: Miletos tipinde amphoralar Pedasa kazıları buluntusu amphoraların yaklaşık \%90 civarındaki bir kısmını oluşturmaktadır. Miletos ve çevresinde yaygın olan bant ve dalgalı çizgi bezeliler (Fig. 1 no: 1-4) ve bezemesiz (Fig. 2 no: 5-9) ticari amphoralar, Miletos tipleri ile kronolojik ve tipolojik birliktelik içerisindedirler. Bu amphoraların Kıyı Karia'nın amphora tiplerini oluşturması, bölgede birçok yerde üretilmiş olabileceklerine işaret etmektedir. Pedasa buluntularının önemli bir kısmının ise Miletos kaynaklı olduğu önerilmektedir. Mykale ile Bybassos arasındaki bölgesel amphora üretiminin, Miletos'un Arkaik Dönem ticaretinin boyutlarına etkisi ancak kil analizlerinin yapılmasından sonra anlaşılabilecektir. Üretim bölgesinin coğrafi boyutu göz önüne alındığında, Miletoslu ve Karialı tüccarların Miletos tipinde amphoralarla taşıdıkları ticari değere dönüşmüş tarımsal ürünlerin, Arkaik Dönem ticaretinde önemli bir paya sahip olmadığı görülmektedir. Bu yorum tarımsal ürünlerin sadece yerel amphoralarla taşınması durumunda geçerlidir. Amphoraların bölgesel dağılımı, yakın bölgelerarası ticari ilişkilerin anlaşımasına katkı sağlamaktadır. Knidos ve Kos'un şarabı ve Keramos Körfezi kuzeyinde üretilen zeytinyağı, Miletos tipinde amphoralarla taşınarak, Miletos başta olmak üzere Pedasa, lasos gibi bölge yerleşimlerinde yerel ihtiyacı karşılamak üzere kullanılmış olmalıdır.

Anahtar sözcükler: Karia, Pedasa, Arkaik Seramik, Miletos Tipinde Amphora

Abstract: First observations from Pedasa excavations attest that nearly \%90 of all Archaic amphorae from the site are of Milesian type. Amphorae with banded and wavy lined decoration (Fig. 1 no: 1-4) which are common at Miletus and its environs and trade amphorae without any decoration (Fig. 2 no: 5-9) are infact related chronologically and typologically. Milesian types might have been produced in several places in the region since they form the major amphora type of Coastal Caria. However, It seems likely that most amphora finds from Pedasa might actually have Milesian origin. Clay analyses would contribute to our understanding of the impact of regional scale amphora production taken place between Mycale and Bybassos on the trade connections of Archaic Miletos. Considering the geographical extend of the production area, agricultural commodities carried in Milesian type amphorae distributed by Milesian and Carian merchants do not have a significant place in Archaic trade. This suggestion is true if amphora is taken as the only vessel for transportation of the commodities. Regional distribution of amphorae contributes to the understanding of interregional trade relations. Knidian and Koan wines and olive oil produced in the north of Keramos Gulf may have been transported in Milesian type amphorae for local use in the cities of the region including Miletos, Pedasa and lasos.

Keywords: Caria, Pedasa, Archaic Pottery, Milesian Type Amphora

* Dr. Öğr. Ü., Muğla Sıtkı Koçman Üniversitesi, Edebiyat Fakültesi, Arkeoloji Bölümü, Muğla, bekirozer@mu.edu.tr 
Giriş

Arkaik Dönem Doğu Ege arkeolojisinin önemli çalışma alanlarından birisini ticari amphoralar oluşturmaktadır. Ticari amphoraların üretim merkezlerinin doğru tanımlanması, söz konusu merkezin tarımsal üretimlerini, denizaşırı ve ticari ilişkilerini tüm boyutları ile anlamamıza ciddi katkılar sağlamaktadır. Ionia merkezlerinden Khios, Klazomenai, Miletos ve Samos, Aiolis'ten ise Lesbos, Arkaik Dönem'in önemli üretim merkezleri arasında yer alırlar ${ }^{1}$. Artan kazı ve araştırmalar bu merkezlere $\operatorname{Teos}^{2}$ ve Erythrai ${ }^{3}$ gibi yeni merkezleri de eklemektedir. Sıralanan bu merkezlerin üretmiş oldukları amphora tiplerinin genel form ve bezeme özellikleri kısmen tanımlanmış ve kabul görmüştür. Dupont'un Zeest-Samos/Protothasos grubu', Birzescu'nun Ionien $I^{5}$ ve Sezgin'in Ionia $\beta^{6}$ olarak isimlendirdiği, Ionia Bölgesi üretimi olan amphoraların henüz hangi yerleşimle bağlantılı olduğu açıklığa kavuşmamış olmakla birlikte, kil analizi sonuçlarına göre daha çok Kuzey Ionia yöresiyle ilişkili olduğu önerilmektedir?. Miletos amphoraları olarak tanımlanmıs olan amphora grubu ise tip ve bezeme çeşitliliği ile diğer merkezlerde üretilen amphoralardan ayrılmaktadır. Genel olarak çoklu üretim merkezi önerisi kabul edilmekte ve Miletos'un güneyindeki Karia Bölgesi'nde de Miletos tipinde amphora üretildiği varsayılmakta$d ı r^{8}$. Bugüne kadar yapılan arkeolojik ve arkeometrik araştırmalar, amphora üretim merkezlerinin aynı zamanda önemli seramik üretim merkezleri de olduğunu göstermektedir ${ }^{9}$. Pedasa'da 2007 yıından bu yana devam etmekte olan kazı çalışmaları, literatüre Miletos tipi amphora olarak girmiş amphoraların, yerleşimde sıra dışı temsil edilme oranına sahip olduğunu göstermektedir. Bu çalışma, Pedasa buluntusu Miletos tipinde amphoralar ile ilgili ön rapor niteliğinde bir çalışmadır ve bunların Karia'da bulunma ve üretilme sebepleri ve sonuçları üzerine bazı gözlem ve yorumları içermektedir.

Kıyı Karia Arkaik Dönem Seramiği ve Ticari Amphoralar: Araştırma Tarihçesi ve Bugünkü Durum 1990'lı yıllardan itibaren Kıyı Karia yerleşim ve kutsal alanlarında artan kazı ve araştırmalar, bölgenin Arkaik Dönem seramik grupları ve sıklıkla tercih edilen vazo formlarının neler olduğu konusunda önemli veriler sağlamıştır. Datça Burgaz/Eski Knidos ${ }^{10}$ ve Emecik Apollon Kutsal Alanı ${ }^{11}$, Leleg Yarımadası Pedasa ${ }^{12}$ ve Asarlık ${ }^{13}$ kazıları, bugünkü bilgilerimizi borçlu olduğumuz belli başlı kazı alanları arasında yer alıılar. Bu merkezlerde gerçekleştirilen kazı çalışmaları, Kıyı Karia'da Arkaik Dönem'de kullanımda olan bezemeli seramiğin, literatürde Doğu Dor seramiği olarak isimlendirilmiş seramiklerden oluştuğunu göstermiştir ${ }^{14}$. Yazar, Dorlar dışında Lelegler ve Karialıların yaşadığı Kıyı Karia'da seramik kullanımında gözlenen ortaklıktan yola çıkarak, bölge seramiklerinin Kıyı Karia Arkaik Seramiği ya da daha geniş bir bakış açısıyla, Güneydoğu Ege Arkaik Seramiği olarak adlandııımasını önermiştir ${ }^{15}$. Arkeoloji dünyasına yeni tanıtılan Kıyı Karia kazıla-

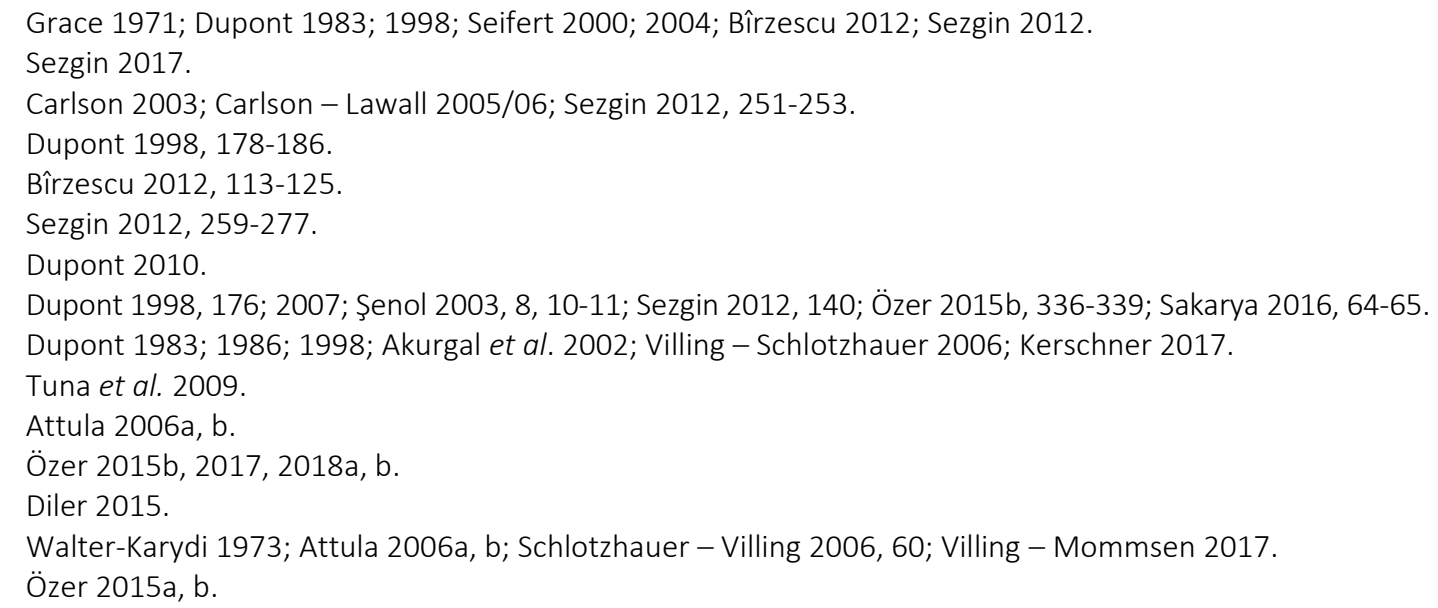


rında ele geçen Arkaik Dönem seramikleri arasında segmentli tabaklar ${ }^{16}$, kaseler $^{17}$, kabartmalı pithoslar ve ticari amphoralar yer almaktadır ${ }^{18}$. Bunların yanı sıra, bant bezeli olpeler ve tabaklar, mortarlar ${ }^{19}$, bantlı ve dalgalı çizgili seramikler, kandiller, çift veya tek kulplu pişirme kapları, sıklıkla karşılaşılan ithal ve yerel seramik tiplerini oluşturmaktadır. Bu çalışmanın konusunu oluşturan Miletos tipinde amphoralar, Knidos Yarımadası'nda oldukça iyi temsil edilmelerine rağmen, buluntularının önemli bir kısmı yayınlanmış olan Emecik Apollon Kutsal Alanı'nın seramikleri arasında tanıtılmamışlardır.

Kıyı Karia'da yaşayan farklı etnik kökene sahip toplulukların ortak seramik geleneğine sahip olduğunu tartışması bir şekilde somutlaştıran ve şüpheye ver vermeyecek şeklide kanıtlayan vazo formları nelerdir sorusuna verilecek cevapta ilk sıraları kaseler ve Miletos tipinde amphoralar alır. 1993 yılından bu yana kazı çalışmalarının gerçekleştirildiği Datça Burgaz/Eski Knidos kazıları Arkaik Dönem buluntuları arasında çok sayıda Miletos tipinde amphora yer almaktadır ${ }^{20}$. Bunlar, Klasik Dönem konutlarının temel dolguları ve yine konutlarla ilişkili Arkaik Dönem tabakalarından ele geçmektedirler. Miletos tipinde amphoralar, Samos-Miletos tipi olarak sınıflananlarla birlikte, Burgaz buluntusu Arkaik Dönem amphoralarının çoğunluğunu oluşturmaktadır ${ }^{21}$. Datça Reşadiye seramik atölyeleri kazılarında ortaya çıkarılan Arkaik Dönem'e ait bir seramik çöplüğünde, amphora üretim artıklarının belgelenmesi, Datça Burgaz kazı verilerinden birkaç yıl önce Knidos'un Miletos ve Samos-Miletos tipinde amphora üretmiş olduğunu tartışmaya açmış$\operatorname{tır}^{22}$. Emecik Apollon Kutsal Alanı buluntularının kil analizleri, Knidos Yarımadası'nın bölgenin önemli seramik üretim alanı olduğunu da göstermiştir ${ }^{23}$. Burgaz kazılarında ortaya çıkarılmakta olan çok sayıdaki Miletos ve Samos-Miletos tipinde amphora, daha önceki çalışmalarda önerildiği gibi ${ }^{24}$, Knidos Yarımadası üretimleri olarak görülmelidirler.

Leleg Yarımadası'na gelindiğinde ise, verilerin 1950'li yıllardan bu yana arttığı izlenir. Bean ve Cook'un 1950'li yılların başlarındaki araştırmalarında, Leleg Yarımadası merkezlerinde genellikle Klasik Dönem'le ilişkili amphora buluntularından söz edilir ${ }^{25}$, ancak çizim ve fotoğraf yayınlanmamış olması buluntuları tanımlama şansı vermemektedir. Asarlık buluntusu bir amphora ${ }^{26}, \mathrm{Ka}-$ ria'nın Miletos tipi amphoraların önemli dağılım alanlarından biri olduğunun habercisidir. Burada 2012 yılında gerçekleştirilen kurtarma kazıları ve devam etmekte olan yüzey araştırmaları, Miletos tipi amphoralara yeni buluntular eklemiştir. Radt tarafından yarımadada gerçekleştirilen araştırmalarda, çoğunlukla Leleglerle ilişkilendirilen yerleşimlerden toplanan seramik parçaları arasında Miletos tipi amphoralar oldukça iyi temsil edilmektedir ${ }^{27}$. Iasos kazıları Miletos tipi amphoraların ele geçtiği diğer önemli bir yerleşim olarak, amphoraların bölgedeki dağılım haritasında yerini alır ${ }^{28}$.

Kıуı Karia'da devam etmekte olan kazılar içerisinde bölgenin materyal kültürünü en iyi

16 Attula 2006a, b.

17 Attula 2006b; Özer 2018a.

18 Özer 2015a, b; Sakarya 2016.

19 Özer 2017.

20 Sakarya 2016, 64-65, 102-106 pl. 1-5, 57-59.

Sakarya 2016, 65-66 pl. 7-12.

Şenol 2003, 8.

23 Mommsen et al. 2006; Attula 2005/06.

24 Şenol 2003, 8; Sakarya 2016, 64-66.

25 Bean-Cook 1955, 122-123, 125, 132, 134.

26 Kleiner et al. 1967, abb. 83 a, b.

27 Radt 1970, Girel Kalesi: abb. 27 no: 1, Ören Avlusu: abb. 27 no: 2-3, Tırman Sivrisi abb. 28 no: 1, Koca Dağ: abb. 28 no: $2-5$.

28 Ibba 2004, fig/kat no. 1-2, 5-6, 27-28; Donati 2013, fig. 5b, kat. no. 2, tav. III a kat. no. 5. 
yansıtan verilerin ortaya çıkarıldığı merkezlerin başında Burgaz ve lasos'un yanı sıra, Pedasa da gelmektedir. Pedasa'da devam etmekte olan kazılarda; tümülüs ve mezar platformlarından oluşan geniş alanlara yayılmış nekropolis'ler, akropolis, Athena Kutsal Alanı, çiftlik evleri, tepeler ve yamaçlar üzerine yerleşik konut grupları ile Leleg Yarımadası'nın belki de en önemli yerleşimi ortaya çıkarılmaktadır. Kent ve çevresinde yürütülen kazılarda, Arkaik Dönem seramiklerinin hangi gruplardan ve vazo formlarından oluştuğunu gösteren bulgulara ulaşılmıştır ${ }^{29}$. Arkaik Dönem'e tarihlenen amphoralar arasında en yaygın olan ve neredeyse tüm amphoraların yaklaşık \%90 civarındaki yoğunluğunu oluşturanların Miletos tipinde oldukları görülmektedir. Pedasa'da Athena Kutsal Alanı'nda Arkaik (Fig. 1 no: 1-2) ve Klasik (Fig. 1 no: 3, Fig. 2 no: 5) dönemlerde inşa edilmiş terasların dolguları, kutsal alan taş döşeli yol sondajları (Fig. 2 no: 6, 9), akropol iç sur enkazı, alt sur kule sondaj kazıları, Gökçeler Mevkii Arkaik Dönem konutları (Fig. 2 no: 7), tümülüsler (Fig. 2 no: 8) ve çiftlik evleri, amphoraların ele geçtiği belli başlı kazı alanları ve yapı tiplerini oluşturmaktadır.

Halikarnassos'un hemen doğu kıyılarında bulunarak kazısı gerçekleştirilen ve MÖ VI. yüzyılın ikinci çeyreğine tarihlenen Pabuçburnu Batığı, Miletos tipi amphoraların Kıyı Karia'da temsil edilme zenginliğini yansıtır ${ }^{30}$. Batıktan ele geçen 6 farklı amphora tipi içerisinde yayıncıları tarafından, ihtiyatı bir şekilde Halikarnassos üretimi olarak tanımlanan ve Miletos amphoralarının form özelliklerini tekrar eden tip, en kalabalık grubu oluşturmaktadır. Tan-Fabric Southern Ionian Type ve South Ionian Slipped Type başlıkları altında tanıtılan diğer amphoralar da, Güney İonia ve muhtemelen Miletos tipleri ile ilişkili örneklerden oluşmaktadır. Pabuçburnu Batığı buluntularının buluntu karakteri, geminin yerel bir gemi olarak yorumlanmasına sebep olmuştur. Amphoraların bölgesel tiplerden oluşması ve diğer kap formlarının bölge kazılarından iyi bilinen örnekleri tekrar etmesi, geminin yerel karakterini güçlendiren verileri oluşturmaktadır.

Yukarıda sıralanan önemli yerleşimler ve kazı merkezleri dışında Alazeytin, Kindya, Kaplan Dağ, Madnasa, Belentepe, Hüsamlar ve Bybassos, Kıyı Karia ve yakın geri bölgelerde, Miletos tipi amphoralar ile sıklıkla karşılaşılan yerleşimler arasında yer alırlar ${ }^{31}$. Aslında nerede bir kazı veya araştırma yapılıyorsa, Miletos tipi amphoralar buraların buluntu envanterinde ilk sıralarda yer alır demek yanlış olmayacaktır.

\section{Pedasa'dan Miletos Tipinde Amphoralar}

Doğu Ege yerleşimlerinde yürütülen kazılarda ortaya çıkarılan amphoraların en kalabalık grubu oluşturan örneklerinin yerel üretim olduğu anlaşılmıştır. Klazomenai ve Miletos kazı verileri ve ilgili yayınlar bu merkezlerden ele geçen Arkaik Dönem amphoralarının en büyük grubunun, ki bazen Miletos'ta olduğu gibi \%90 civarında bir temsil oranından bahsedilir, yerel üretim olduğunu göstermiştir ${ }^{32}$. Miletos'ta arkeolojik olarak belgelenen bu durum, kil analizleri ile de desteklenmiştir ${ }^{33}$. Klazomenai ve Miletos kazılarından elde edilen bu verinin Doğu Ege yerleşimleri ya da seramik ürettiği bilinen İonia yerleşimleri özelinde genel geçer bir kural olarak kabul edilmesi durumunda, rahatlıkla Pedasa'nın Miletos tipinde amphora üretimi yapmış önemli bir merkez olduğu çıkarımında bulunulabilirdi. Ancak Pedasa kazı ve araştırmalarında bugüne kadar ortaya çıkarılmış olan seramik buluntular, yerleşim merkezinde, muhtemelen bazı çömlek formları dışında seramik üretildiğini gösteren veriler sağlamamıştır. Pedasa toplumunun kullandığı çanak çömlek, büyük oranda yakın bölgelerden, Miletos ile Knidos arasındaki üretim yerlerinden gel-

\footnotetext{
29 Özer 2015b; 2017; 2018a, b.

30 Greene et al. 2008; Greene - Lawall 2005/06.

31 Miletos tipinde amphoraların bölgedeki buluntu yerleri için bk.: Özer 2015b, harita.

32 Naso 2005, 74, 78; Sezgin 2012, 24; Bîrzescu 2012, 205.

33 Seifert - Yalçın 1994; Dupont 1998, 174; Seifert 2000; 2004; Kerschner - Mommsen 2005
} 
miştir $^{34}$. Buluntuların bölgesel niteliği ve Güney lonia ithallerinin ya da taklitlerinin yerel ihtiyacı karşılayan yoğunluğu, bu yorumun yapılmasına dayanak oluşturmuştur. Şüphesiz kesin sonuçlar için farklı vazo formlarından inandırıcı sayıda buluntunun kil analizlerinin yapılması zorunludur.

Pedasa buluntusu amphoralar ile ilgili ilk gözlemler, Miletos amphoraları olarak tanımlanan amphoraların birçok tipinin Arkaik Dönem boyunca Pedasa'da yaygın olarak temsil edildiğine işaret etmektedir. Yüksek, ince, içbükey ağız kenarı, boynun üst kısmındaki set/setler veya plastik bant ve omuza geçişteki plastik çıkıntı, standartlaşmış Miletos amphoralarının form özelliklerini tanımlar ${ }^{35}$. Bu özelliklere sahip tipler dışında, yüksek kalın oval, üstte ince veya kalın olabilen, altta ise köşeli ya da oval görünümlü ağız ve badem ağızlı tiplerin de oldukça yaygın olduğu görülmektedir. Form çeşitliğinde görülen bu zenginlik, araştırmacılara Miletos dışında başka merkezlerde de üretim yapılmış olabileceğini düşündürtmüştür. Çağdaş olarak gözlenen form çeşitliliği ve bazı tiplerin uzun zaman üretilmiş olması, Miletos tipinde amphoraların kronolojilerinin sağııkı bir şekilde oluşturulmasını güçleştirmektedir.

Bu çalışmada yer verilen amphoralar, Pedasa buluntularından seçilmiş bazı örneklerden oluşmaktadır ve bugüne kadar yapılan arkeolojik ve arkeometrik çalışmalarda Miletos tipi olarak tanımlanan örneklerle yakın benzerlikleri, Miletos, Assesos, Didyma ve Teikhiussa gibi merkezlerde çok bulunmaları gibi sebeplerle Miletos tipi amphora olarak değerlendirilmişlerdir. Sıralanan merkezlerin buluntularının ortaklığı, bölgesel tiplerin zenginliğini yansıtmakta, çekirdek üretim, kullanım ve dağıım bölgesinin anlaşılmasını sağlamaktadır.

\section{Bantlı ve Dalgalı Çizgi Bezeli Amphoralar (Fig. 1 no: 1-4)}

1-4 no.lu amphora ağız boyun parçaları Seifert, Naso, Bîrzescu ve Sezgin'in Miletos tipi amphoralarla ilgili yaptıkları çalışmalarda tanıttıkları amphoralarla benzerliklerinin yanı sıra, Güney lonia ve Karia'da oldukça iyi temsil edilmeleri sebebiyle Miletos amphora tipleri arasında değerlendirilmişlerdir ${ }^{36}$. Miletos, Assesos ${ }^{37}$, Didyma ${ }^{38}$ ve Teikhiussa ${ }^{39}$ buluntuları, bezemeli ve bezemesiz amphoraların bölgedeki yaygınlıklarına işaret etmekte ve bazı tiplerin paralel form değişimi geçirdikleri görülmektedir. Miletos, Assesos ve Didyma kazıları, Arkaik Dönem içerisinde farklı ă̆ız profili ve bezeme anlayışına sahip amphoraların bir arada kullanımda olduklarını gösteren yeterince veri sağlamıştır.

1 no.lu parça, dışa çekik kalın ağız kenarı ile Miletos ${ }^{40}$, Assesos ${ }^{41}$, Didyma ${ }^{42}$, Mykale $^{43}$ ve Burgaz' dan ${ }^{44}$ yayınlanmış amphoralar ile yakın form özelliği göstermektedir. Benzer ağız profiline sahip amphoralarda ağız ve boyun bantlar ile bezeli ya da bezemesiz olabilmektedir. 2 no.lu parça, kalın içe ve dışa doğru çekilmiş ağız kenarı, içte, altta içbükey/oyuk profili ile ve her ne kadar ağız kenarı daha kısa olsa da, Seifert'in 5 a grubu ${ }^{45}$, Didyma ${ }^{46}$, Ören Avlu ${ }^{47}$ ve Burgaz ${ }^{48}$ buluntuları ile

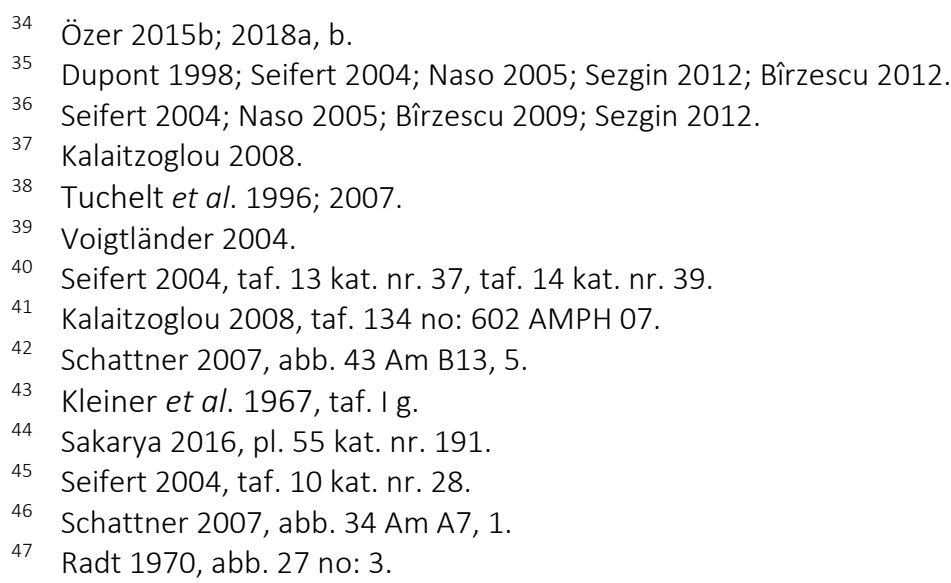


benzerdir. Ağız kenarında, iki firnis bant arasında yer alan rezerve bant, Güney İonia'nın MÖ VII. yüzyıl seramiğinde görülmekte, en geç MÖ VI. yüzyılın başlarında başlayan yaygın kullanımının amphoralar ve hydrialar başta olmak üzere farklı vazo formlarında artarak devam ettiği izlenmektedir ${ }^{49} .1$ no.lu parça, MÖ VI. yüzyılın ortalarından önce inşa edilmiş teras duvarının gerisindeki hareketli anakaya yükseltilerin arası ve üzerini kapatmak amacıyla atılmıs dolgu ile ilişkilidir. 2 no.lu parça ise, söz konusu teras duvarının hemen gerisine atılmış dolgudan ele geçmiş̧ir. Beraber ele geçtiği buluntular, MÖ VII. yüzyıl ve VI. yüzyılın ilk yarısına tarihlenir. Her iki parçanın kontekst verileri, MÖ VI. yüzyılın ortalarından sonraya ait olamayacaklarına işaret eder. 1 ve 2 no.lu amphora ağız parçaları, benzer Miletos buluntuları için önerilmiş olan MÖ VII. yüzyılın ikinci yarısına tarihlenebilir ${ }^{50}$.

3 ve 4 no.lu örnekler, Miletos başta olmak üzere Didyma gibi bölge merkezlerinden oldukça iyi tanınan bant bezeli amphoraların genel form ve bezeme

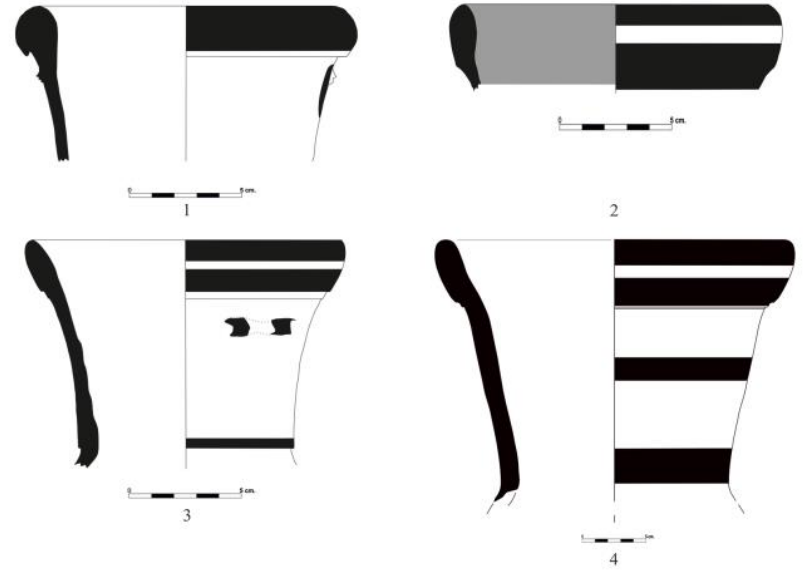

Fig. 1-4
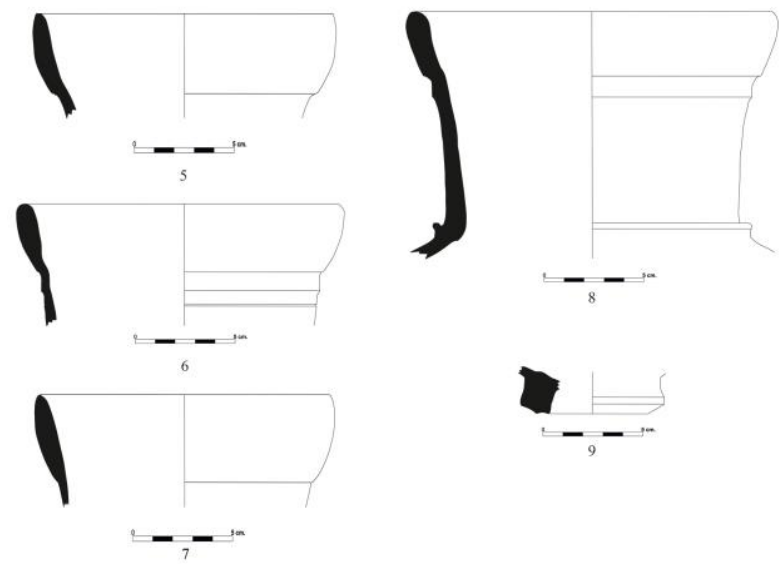

Fig. 5-9 özelliklerini tekrar etmektedirler. Bezemesiz amphoralar ile de benzer form özelliklerini paylaşırlar. Bîrzescu'nun Oikos ve Histria 6. Tip, Sezgin'in Mil5 grubu ile ilişkilidirler ${ }^{51}$. Yüksek oval, içbükey ya da badem formunda ağız, bazı örneklerde ağzın hemen altındaki set, omuza geçişte oldukça belirgin plastik bant, formun genel özelliklerini tanımlar. Boyundan omuza geçişte görülen plastik çıkıntı, aynen Fikellura stilinde bezeli amphoralarda ${ }^{52}$ olduğu gibi belirleyici bir özelliktir. Bazı örneklerde boyundan omuza geçişte oyuk ${ }^{53}$ görülürken, bazılarında geçiş aynen 4 no.lu parçada olduğu gibi, daha yumuşak verilmiştir ${ }^{54}$.

3 no.lu örnekte boyunda izlenen iki sıradan oluşan dalgalı çizginin Miletos seramiğinde Arkaik Dönem boyunca oldukça sık karşılaşılan bir bezeme elemanı olduğu görülmektedir ${ }^{55}$. Bîrzescu'nun Oikos tip grubunda tanıttığı 3 ve 4 no.lu parçalar ile benzer ağız profiline ve bant düzenlemesine sahip örneklerin boyunları tek dalgalı çizgi ile bezelidir ${ }^{56}$. Form ve bezeme olarak

49 Seifert 2004, taf. 27 kat nr. 70, taf. 28 ve çok sayıda başka örnek; Schattner 2007, abb. 32-41, 45; Kalaitzoglou 2008, taf. 124 no: 558 HYD 05, taf. 125; Bîrzescu 2009; Waldbaum 2011, kat. nr. 501-502, 550.

50 Seifert 2004, 13, 15.

51 Bîrzescu 2009; 2012, 142 taf. 61; Sezgin 2012, 156-159.

52 Wascheck 2008; Sezgin 2012, 303.

53 Seifert 2004, taf. 35 kat. nr. 94, taf. 42 kat. nr. 108.

54 Seifert 2004, taf. 28 kat. nr. 75; Bîrzescu 2009, abb. 2 kat. 4.

55 Seifert 2004, taf. 4 kat. nr. 12, taf. 5 kat. nr. 15, taf, 7-8 ve çok sayıda başka örnek.

56 Bîrzescu 2009. 
benzerleri Seifert tarafından amphoralar, Kalaitzoglou tarafından ise hydrialar arasında listelenmiştir $^{57}$. Küçük parçalar şeklinde korunmuş örneklerin hangi forma ait olduğunu söyleyebilmek mümkün görünmemektedir. Form ve bezeme bakımından benzer ve ilişkili amphoralar çok sayıda merkezden bilinmektedir ${ }^{58}$. Ashkelon'dan oldukça benzer bir form hydria olarak yayınlanmışıı ${ }^{59}$.

4 no.lu örnek, yüksek kalınlaşmış içbükey ağız profili ve ağız dış kenar bezemesi ile Miletos tipi amphoraların tipik bir üyesidir. Boyunda ise kalın yatay bant ile bezenmiştir. Dalgalı çizgi bezemesi kadar yaygın olmasa da, boyun üzerinde yer alan bant bezeme Miletos seramiğinde görülmekte ${ }^{60}$, parça form özelliği ile Miletos serileri arasında yer bulmakta ve bölge merkezlerinde temsil edilmektedir ${ }^{61}$.

Her iki Pedasa parçası, MÖ IV. yüzyılın ortalarından sonra inşa edilmiş büyük teras duvarının gerisine atılmış dolgulardan ele geçmiştir. 4 no.lu parçanın ele geçtiği dolgu paketinin kutsal alandaki bothroslarla ilişkili olduğu daha önce tartışılmıştır ${ }^{62}$. Illgili seviyelerden ele geçen buluntuların büyük bölümü MÖ VII. yüzyılın sonları ve VI. yüzyılın ilk yarısına tarihlenir. Her iki parça ile benzer buluntuların genellikle MÖ VI. yüzyılın ikinci yarısına tarihlendiği görülmektedir ${ }^{63}$. Parçalarda görülen form ve bezeme özelliklerinin MÖ VI. yüzyılın ikinci yarısı ile sınırlı kalmaması, MÖ VII. yüzyılın sonlarından itibaren görülmesi ${ }^{64}$ ve kontekst verileri doğrultusunda, MÖ VI. yüzyılın ikinci ve üçüncü çeyreklerine tarihlendirilebilirler.

Miletos Zeytintepe Aphrodite Kutsal Alanı'ndan, tanrıçanın adının yazdığı dipontolu bir amphoranın ortaya çıkarılmış olması, bant ve dalgalı çizgi bezeli amphoraların kutsal alan için üretildikleri şeklinde yorumlanmasına sebep olmuştur ${ }^{65}$. Bant bezeli Pedasa buluntularının büyük çoğunluğunun Athena Kutsal Alanı'ndan ele geçmesi, burada da bu tip amphoraların kült envanterinin parçası olabileceğine işaret eder. Benzer amphoraların denizaşırı yerleşimlerde az bulunması, az sayıda ihraç edilmeleriyle bağlantılı görülmüştürr ${ }^{66}$. Miletos ve çevresi dışında Pedasa'da da dikkat çeken buluntu yoğunluğu, bu tip amphoraların bölge materyal kültürünün, özellikle de kutsal alanların ${ }^{67}$ önemli bir parçası olduğunu belgelemekte ve Miletos yarımadasına aidiyetini güçlendirmektedir. Samos üretimi olduğu önerilen Heraion buluntusu band bezeli ya da bezemesiz amphoraların da kült amphorası olarak tanıtıldığı görülmektedir ${ }^{68}$.

\section{Bezemesiz Ticari Amphoralar (Fig. 2 no: 5-9)}

5 no.lu parça yüksek, iç bükey ağız profili ile en geç MÖ VII. yüzyılın ortalarında standartlaşan ${ }^{69}$ Miletos tipi amphoraların daha geç bir temsilcisidir. MÖ VII. yüzyılın ortaları ve üçüncü çeyreğine ait örneklere göre ağız kenarı daha incedir. Pedasa parçasının korunma durumu bu tip amphora-

57 Seifert 2004, taf. 28 kat. nr. 75, Taf. 33 kat. nr. 87, Taf. 35 kat. nr. 94; Kalaitzoglou 2008, taf. 126 no: 562 AMPH 11a.

58 Miletos: detaylı literatür ile birlikte Bîrzescu 2009, abb. 6 kat. 10; Didyma: Schattner 2007, abb. 36 Am B1, 12, abb. 38 Am B4, 3; Teichiussa: Voigtländer 2004, taf. 166 no: 131; Ören Avlusu: Radt 1970, abb. 27 no: 2; Histria: Bîrzescu 2012, taf. 61 no: 1273.

59 Waldbaum 2011, kat. 550.

60 Seifert 2004, taf. 4 kat. nr. 11, taf. 18 kat. nr. 48, taf. 50 kat. nr. 121; Kalaitzoglou 2008, taf. 124 no: 558 HYD 05.

61 Seifert 2004, taf. 26 kat. nr. 69, taf. 32 kat. nr. 84, taf. 39 kat. nr. 101; Schattner 2007, abb. 38 Am B4, abb. 39 Am B4, 24.

62 Özer 2018b

63 Seifert 2004, 17; Bîrzescu 2009; Sezgin 2012, 158-159.

64 Waldbaum 2011, 325-326; Bîrzescu 2012, 142.

65 Bîrzescu 2009,125, 134.

66 Bîrzescu 2009, 125; Dağılım haritası için bk.: Bîrzescu 2012, abb. 60.

67 Schattner 2007, 479 tab. 37.

68 Furtwängler - Kienast 1989, 92-94.

69 Bîrzescu 2009, abb.1; Greene et al. 2013, fig. 3. 
larda genellikle gözlenen ve boynun üst bölümünde yer alan setlere ${ }^{70}$ sahip olup olmadığı konusunda herhangi bir yorumda bulunmayı mümkün kılmaz. Benzer ağız profiline sahip amphora parçaları Burgaz buluntuları arasında da oldukça iyi temsil edilmektedir ${ }^{71}$. Bazı benzer örneklerin kil ve katkı özelliklerinin yerel seramik grupları ile yakın benzerliği ve Burgaz'da iyi temsil ediliyor olmalarından dolayı Knidos bölgesi üretimleri oldukları önerilmiştir ${ }^{72}$. Kalın ağız kenarlı, içbükey ağız profilli amphoralara MÖ VII. yüzyılın ortalarından itibaren gemi kargolarında yer verilmiş olması $^{73}$, Knidoslu üreticilerin Miletos kaynaklı bu amphoralardan etkilenerek, vakit kaybetmeden üretim yapmış olabileceklerini akla getirmektedir. Dolayısıyla, Güney lonia'da Miletos öncülüğünde standartlaşan amphora tipleri, yakın bölgelerin kendi tiplerinin yaratılmasını etkilemiş olmalıdır. Formun Miletos'a aidiyetini Miletos kaynaklı figürlü seramik örneklerinde de benzer formun MÖ VII. yüzyıl içlerinden ${ }^{74}$, VI. yüzyılın ikinci yarısında Fikellura stilinde bezeli amphoralarda da devam etmesi ${ }^{75}$, şüpheye yer bırakmayacak şekilde güçlendirmektedir. 5 no.lu parçanın ait olduğu amphora grubu, bölge merkezleri ve denizaşırı yerleşimlerde bant bezeli ya da bezemesiz örneklerle oldukça iyi temsil edilmektedir ${ }^{76}$. 5 no.lu parça, MÖ VII. yüzyılın sonları VI. yüzyılın ilk yarısına tarihlenen Miletos amphoraları ile olan yakın form benzerliği ve dolaylı da olsa kontekst verileri nedeniyle, benzer şekilde tarihlenebilir ${ }^{77}$. MÖ IV. yüzyılın ortalarından sonra inşa edilmiş olan büyük teras duvarının dolgusundan ele geçmiştir. Aynı seviyeden ele geçen buluntuların büyük çoğunluğu MÖ VI. yüzyılın ilk yarısına, bir kısmı ise Klasik Dönem'e aittir.

Zengin form çeşitliliğine sahip Miletos tipi amphoraların bazı tipleri ile kalın, altta içbükey yüksek ağız profili ve boynun üst kısmındaki set ile benzer özelliklere sahip olmakla birlikte ${ }^{78}, 6$ no.lu parçanı ${ }^{79}$ bu tiplerle doğrudan ilişkisi olduğunu söylemek oldukça zordur. Miletos tipinde amphoraların Kıyı Karia'da üretilmiş yerel bir temsilcisi olmalıdır. Boyundaki ince yiv ise Bîrzescu'nun Ionia I, Tip 2 grubu, Sezgin'in Ionia $\beta 1$ ve 2 grupları ile ilişkili amphoralardan bilinmektedir $^{80}$. Miletos buluntuları arasında benzer ağız profiline sahip bant ve dalgalı çizgi bezeli örnekler bulunmaktadır ${ }^{81}$. Benzer ağız profili ile ilişkili amphora tiplerinin MÖ VI. yüzyıl, genellikle yüzyılın ikinci yarısına tarihlendirildiği görülmektedirr ${ }^{82}$. Antik Yol Sondajı, MÖ IV. yüzyıla tarihlenen yol döşemesi tesviye dolgusundan ele geçen parçanın kontekst verileri tarihlemede yardımcı olmamaktadır. Ele geçtiği dolgu, Klasik Dönem ve MÖ VI. yüzyıla ait buluntuları içermektedir.

7 no.lu parça, Miletos tipinde amphoralar için kullanılan oval kesitli tip tanımlaması ile tamamen örtüşmektedir. Korunma durumundan dolayı boyun profil detaylandırması bilinmiyor olsa da, benzer formun Güneydoğu Ege ya da Miletos kaynaklı olduğu, bölge amphora tipleri

70 Dupont 1998, fig. 23. 7-8; Sezgin 2012, 170-172; Bîrzescu 2012, taf. 57-61.

71 Sakarya 2016, pl. 58 kat. nr. 206.

72 Sakarya 2016, 64-65.

73 Greene et al. 2013, fig. 3.

74 Kalaitzoglou 2008, taf. 138 AMPH 03.

75 Wascheck 2008, abb. 4a, 5a, 6a, 7a, 13a, 14a, 16a, 22.

76 Miletos: Seifert 2004, taf. 25 kat. nr. 65-66; Naso 2005, fig. 2 cat. 4; Didyma: Schattner 2007, abb. 33 Am A2, 12, abb. 34 Am A3; Mykale: Lüdorf 2007, abb. 55 MYK 140-570-06; Ephesos: Kerschner - Mommsen 2005, abb. 2; Histria: Bîrzescu 2012, taf. 57 no: 1179; Orgame: Mănucu-Adameşteanu 2008, pl. XVIII no: 209; Bels: Zadnikov 2006, fig. 4 no: 1; Bulgaristan: Tzochev 2010, pl. 57 no: 1.

77 Dupont 1998, 174 fig. 23.8a.

78 Ruban 1991, fig. 4.1; Bîrzescu 2012, 139-140 tip 2-4; Sezgin 2012, 154-159 tip 4-5.

79 Özer 2015b, res. 3.

80 Bîrzescu 2012, 115-123; Sezgin 2012, 259-270.

81 Bîrzescu 2009, abb. 3 kat. 5.

82 Miletos: Seifert 2004, taf. 34 kat. nr. 91; Didyma: Schattner 2007, abb. 39 Am B4, 33, abb. 40 Am B4, 43; Teichiussa: Voigtländer 2004, taf. 170 no: 159; Girel Kalesi: Radt 1970, abb. 27 no: 1; Histria: Bîrzescu 2012, taf. 60 no: 1221. 
arasında temsil ediliyor olmalarından dolayı rahatlıkla söylenebilir. Miletos amphora tipleri arasında sınıflandırılmış benzerleri, bant bezeli ya da bezemesiz olabilmektedir ${ }^{83}$. Illişkili amphora grupları genellikle MÖ VI. yüzyılın ikinci yarısına tarihlenmiştir ${ }^{84}$. Pedasa parçası, MÖ VI. yüzyıla ait bir evin buluntularından birisidir. Ele geçtiği konut ile ilgili stratigrafi çalışması tamamlanmamıştır ve kontekst verileri doğrultusunda tarihlendirme henüz yapılamamaktadır. Genel değerlendirmelerde önerilen tarihlendirme çerçevesinde MÖ VI. yüzyııı ikinci yarısına ait olmalıdır.

8 no.lu parça, Pedasa buluntusu amphoralar arasında içbükey ağız profili, ağzın hemen altındaki plastik bantı ve omuz gövde geçişinde izlenen belirgin plastik çıkıntısı ile Miletos tiplerinin ${ }^{85}$ özelliklerini en iyi yansıtan buluntulardan birisidir. Bezemesiz ya da bant veya dalgalı çizgi bezeli, özellikle ağı profili bakımından çok sayıda benzer örnek Güneydoğu Ege ve denizaşırı yerleşimlerden bilinmektedir ${ }^{86} .8$ no.lu parça, Leleg Yarımadası'nın en iyi korunmuş taş tümüslerinden, Gebe Kilise ${ }^{87}$ olarak adlandırılan yapının mezar odası toprağının elenmesi sırasında bulunmuştur. Mezar odasının defalarca tahrip edilmiş olması, 8 no.lu parçanın buluntu yerine göre tarihlendirme yapılabilmesine izin vermemektedir. Form özellikleri, özellikle boyun omuz geçişinde izlenen belirgin plastik çıkıntısı ile, MÖ VI. yüzyılın ikinci yarısına tarihlenen Miletos tipinde amphoralarla yakın benzerlik taşıyor olmasından dolayı, Geç Arkaik Dönem'e tarihlenebilir.

Arkaik Dönem'e ait kaide parçalarının üretim bölge veya merkezinin tanımlanmasının daha sorunlu olduğu görülmektedir. Ayrıca, kaide parçalarının yayınlanmasına olan ilgisizlik durumu daha da güçleştirmektedir. Pedasa'da çok sayıda ağız parçası bulunmuş olmasına rağmen, kaide parçalarının oldukça az sayıda ele geçtiği görülür. 9 no.lu kaide parçası, kısa halka formu, sığ oluklu dip kısmı, oturma düzlemindeki oyuğu ve dıştan köşeli profil özelliğine sahip olması gibi özellikleri ile Miletos ${ }^{88}$ ve Didyma ${ }^{89}$ buluntusu amphoralarla benzerdir. Oturma tabanındaki oyuğu ile çok daha geniş oyuklu Berezan ${ }^{90}$ amphorasını da hatırlatır. Benzer buluntuların genellikle Geç Arkaik Dönem'e tarihlendiği görülmektedir. Antik Yol Sondajı, MÖ IV. yüzyıla tarihlenen yol döşemesi tesviye dolgusundan ele geçen parçanın kontekst verileri tarihlemede yeterince yardımcı olamamaktadır.

\section{Karia'da Miletos Tipinde Amphora Üretimi ve Pedasa Buluntularının Kaynağı}

Arkaik Dönem boyunca Miletos tipindeki amphoraların Kıyı Karia coğrafyasında şaşırtıcı çokluğu ve bazı veriler, Karia coğrafyası topluluklarının Miletos tiplerini takip eden amphora ürettiğinin işaretlerini vermektedir. Bu konudaki arkeolojik kanıtlardan biri, Knidos Yarımadası'ndan gelmiştir. Datça Reşadiye seramik atölyeleri mahallesinde gerçekleştirilen kazılarda, Miletos tipinde

Seifert 2004, taf. 27 kat. nr. 70, taf. 48 kat. nr. 116-117; Naso 2005, fig. 3 no: 10; Bîrzescu 2009, abb. 4 kat. 7.

84 Didyma: Schattner 2007, abb. 36 Am B2, 4, abb. 37 Am B2, 11-13; Teichiussa: Voigtländer 2004, taf. 170 no: 157; Koca Dağ: Radt 1970, abb. 28 no: 5; Aegina: Johnston 1990, fig. 7 no: 109; Histria: Bîrzescu 2012, taf. 60 no: 1225 .

Dupont 1998, fig. 23.7d; Monachov 2003, fig. 18 no: 3; Sezgin 2012, Mil5, Bîrzescu 2012, tip 2 ve 4.

86 Miletos: Seifert 2004, taf. 28 kat. nr. 75, taf. 32 kat. nr. 84, taf. 33 kat. nr. 87-88; Naso 2005, fig. 3 cat. 9-10; Bîrzescu 2009, abb. 4 kat. 8; Didyma: Schattner 2007, abb. 39 Am B4, 34, abb. 40 Am B4, 37; Teichiussa: Voigtländer 2004, taf. 163 no: 113, Taf. 166 no: 129; Asarlık: Kleiner et al. 1967, abb. 83a-b; Burgaz: Sakarya 2016, pl. 58 kat. nr. 207; Ephesos: Kerschner - Mommsen 2005, abb. 10; Histria: Bîrzescu 2012, taf. 60 no: 1224; Orgame: Mănucu-Adameşteanu 2008, pl. XVIII no: 208; Bulgaristan: Tzochev 2010, pl. 57 no: 1; Aegina: Johnston 1990, fig. 7 no: 107.

87 Bean - Cook 1955, 166-167; Radt, 1970, 219-223, 225 abb. 19, taf. 36, 3-4, taf. 37, 1-2; Carstens 2008, 8688 fig. 33-35; Diler 2011, 332-333 res. 13.

88 Bîrzescu 2009, abb. 4 kat. 7.

89 Schattner 1996, abb. 110 Ke 49-51.

90 Sezgin 2012, Mil4.03. 
amphoraların üretim artıklarına rastlanmıştır ${ }^{91}$. Burgaz kazılarında, Miletos ve Samos-Miletos tipi amphoraların Arkaik Dönem amphoraları arasında çokluğu ${ }^{92}$, Reşadiye kazı verilerini ve önerileri desteklemekte ve bölgeye özgü bezemeli seramikte olduğu gibi ${ }^{93}$ Knidos Yarımadası'nın Klasik Dönem öncesinde de ticari amphora üretmiş önemli bir bölge olduğunu da belgelemektedir ${ }^{94}$.

Pabuçburnu Batığı'ndan ortaya çıkarılmış olan amphoralar arasında en kalabalık grubu oluşturan örnekler intiyatlı bir şekilde Halikarnassos üretimi olarak önerilmiştir ${ }^{95}$. Bu önerinin yapılmasında Halikarnassos tipi olarak sınıflanan amphoraların Halikarnassos ve Knidos bölgesi seramiklerinin kil yapısı ile olan benzerliği, önemli dayanak oluşturmuştur. Önerilen bu merkezler dışında Karia kıyısında Bybassos ${ }^{96}$ ve herhangi bir yerleşim adı verilmeden Karia'da birçok yerde ${ }^{97}$ Miletos tipinde amphora üretildiği ileri sürülmüştür.

Önerilen bu merkezlerden bazılarının, Reşadiye ve Bybassos gibi, Klasik ve Hellenistik dönemlerin önemli amphora ve günlük seramik üretim alanları olduğu göz önüne alındığında, Karia kıyısında dere yataklarının hemen yakınına, yerleşim yerleri çevresine veya bölgenin tarımsal potansiyeli ile ilişkili alanlara konumlanmış amphora üretim merkezlerinin bulunduğu alanların (Çamlık, Karaca ve Turgut gibi), muhtemel Arkaik Dönem seramik üretim alanları olarak listeye dahil edilmesi olasıdır ${ }^{98}$.

Miletos tipindeki ticari amphoraların buluntu yerlerinin yerel kaselerle örtüştüğü görülmektedir $^{99}$. Yerel kaselerde gözlenen kil ve katkı çeşitliliği ve bölgelere göre değişen bezeme özellikleri, farklı üretim yerleri olduğuna dönük veriler olarak kabul edilmiş ve Kıyı Karia'da birkaç yerde üretilmiş olabilecekleri önerilmiştir ${ }^{100}$. Bu kaseler için Keramos Körfezi kıyısında yer alan Keramos antik kenti çevresinin olası üretim yerlerinden biri olarak kabul edilmesi durumunda, Miletos tipi amphoralar için de benzer bir önerme yapılabilir. Keramos Körfezi'nin özellikle kuzey kıyılarında belgelenmiş Arkaik Dönem batıkları ve kargolarında bulunan bölge amphora tipleri, bu kıyıların önemini her geçen gün arttırmaktadır ${ }^{101}$.

Kıyı Karia ve karşı adalarda, özellikle Kos ve Nisyros'ta yaygın olan figürlü seramiklerin Knidos Yarımadası dışında, Kos adasında da üretildiği arkeometrik çalışmalar sonucunda anlaşımışı ır ${ }^{102}$. Seramik üretim yerleri arasına Kos'un önemli bir üretim merkezi olarak girmesi ve adanın Klasik Dönem'den itibaren önemli bir amphora üretim merkezi olması ${ }^{103}$, Arkaik Dönem'in amphora üretim bölgelerinden biri olarak kabul edilmesi olasılığını güçlendirir.

lasos ve Hydas gibi, Erken Demir Çağı Karia'sının önemli veri sunan merkezlerinin seramik buluntuları, Mylasa ve Euromos'un da içinde bulunduğu Mandalya körfezi kıyıları ve yakın geri bölgeleri, amphoralar için de olası üretim bölgesi olarak görmemizi gerektirir. Aslında Karia Orientalizan Seramiğinin Miletos atölyelerine öykünerek üretilmiş olması ve üretim bölgesinin Mylasa çevresi ile ilişkilendirilmesi ${ }^{104}$ bölgede Miletos tipinde amphoralar üretilmiş olabileceğine

Şenol 2003, 8; Sezgin 2012, 139.

92 Sakarya 2016, 65-66.

93 Mommsen et al. 2006.

94 Attula 2005/06.

95 Greene - Lawall 2005/06; Greene et al. 2008.

96 Şenol - Şenol 2010.

97 Dupont 1998, 176; Dupont 2007, 621.

98 Empereur - Picon 1986; Doğer 1994; Doğer - Şenol 1996; Cankardaş-Şenol et al. 2004; Özer $2015 b$.

99 Özer 2015b, harita.

100 Özer 2015a, b; 2018a.

101 Greene et al. 2008; Greene et al. 2013.

102 Villing - Mommsen 2017.

103 Kantzia 1994; Hein et al. 2008.

104 Cook 1998, 63-66; 1999; Fazlıoğlu 2007; 2009. 
işaret etmektedir. Son yıllarda Mylasa merkezinde ortaya çıkarılmış olan Hellenistik ve Roma dönemlerine tarihlenen seramik atölyelerinin üretimleri arasında amphoraların önemli miktarlarla temsil edilmesi, bölgede amphora üretiminin daha önceki dönemler için de geçerli olabileceği olasılığını güçlendirmektedir. Şüphesiz Miletos ile coğrafi yakınlık Mylasa ve lasos çevresini amphora üretimi için doğal aday yerler olarak görmemizin diğer bir sebebidir.

Burada çok sayıda yerin üretim merkezi olarak görülmek istenmesi, Miletos ve SamosMiletos tipi amphoralar için son yıllarda daha çok kabul edilmek istenen Güneydoğu Ege üretimleri oldukları ve birçok merkezde üretilmiş olabilecekleri şeklindeki yorumlar ile örtüşmektedir ${ }^{105}$. Klazomenai ve Khios gibi bazı merkezlerin amphora üretimleri, sınırları tanımlı teritoryumlarla ilişkisi olsa da, ticari amphoraların bölgesel üretimler oldukları görüşü ağırlık kazanmaktadır ${ }^{106}$.

Güneydoğu Ege yerleşimlerinin buluntularından anlaşıldığı kadarıyla, Mykale dağlarından Bybassos'a kadar olan coğrafyada Miletos tipi amphoralar temel amphora tiplerini oluşturmaktadır. Yayılım alanı, muhtemelen Ephesos'a kadar uzanmaktadır ${ }^{107}$. Yetersiz kazı ve araştırma, yayılımın güney sınırı için herhangi bir öneride bulunmayı güçleştirir. Karia Khersonesos'u Miletos tipinde amphoraların önemli buluntu alanlarından biri olmaya adaydır.

Burgaz ve çevresinde Miletos tipleri dışında, Samos-Miletos tipi olarak sınıflanan ${ }^{108}$ ve Bîrzescu'nun Ionien I, Sezgin'in Ionia $\beta$ tipleri ile ilişkili amphoraların da temsil ediliyor olması, Knidos Yarımadası ve Güneydoğu Ege'de başka tiplerin de üretiliyor olabileceğine işaret etmektedir. Knidos Yarımadası'nda Miletos tipleri ile başlayan amphora üretimlerinin zamanla yerel tiplerin yaratılması şeklinde geliştiği ve Samos-Miletos tipi olarak sınıflanan tiplerin de üretildikleri, şimdilik kabul edilebilir bir olasılıktır. Güncel durum, Pedasa başta olmak üzere, Keramos Körfezi kuzeyinde, Knidos ve çevresine göre biraz daha farklı görünmektedir. Pedasa'da Arkaik Dönem amphoraları arasında Miletos tipinde olanlar dışında kalan ve dikkat çeken bir yoğunluk oluşturan amphora tipleri ile karşılaşılmamıştır. Burada ve Leleg Yarımadası'nın diğer yerleşimlerinde, Miletos tipinde amphoralar dışında sayısal bakımdan çok daha az temsil edilseler de, Samos başta olmak üzere, Khios amphoraları da ele geçmektedir.

Bugün için cevaplanması gereken en önemli sorulardan biri Pedasa buluntusu Miletos tipinde amphoraların ne kadarının Miletos kökenli ne kadarının Kıyı Karia atölyeleri veya Knidos Yarımadası ile ilişkili olduğudur. İlk gözlemler, Pedasa buluntusu Arkaik Dönem'e ait Miletos tipi amphoraların özellikle bant ve dalgalı çizgili olanlarının neredeyse tamamının doğrudan Miletos ile ilişkili olduğu şeklindedir. Bezemesiz ticari amphoralar için ise durum biraz daha karışık gibi görünmektedir. Burgaz verilerine göre bölgesel üretimlerin varlığı ve özellikle 6 no.lu parçadan da anlaşılacağı gibi hibrid tipler, kil analiz sonuçlarını beklemeyi gerektirmektedir.

\section{Bazı Sorular ve Olası Cevaplar}

Son yıllarda Levant ${ }^{109}$ ve Methone ${ }^{110}$ verileri, Doğu Ege ticari amphoralarının en geç MÖ VII. yüzyılın başlarından itibaren denizaşırı yerleşimlerde görüldüğünü ortaya koymaktadır ${ }^{111}$. Dolayısıyla bu veriler amphora ile yapılan ürün ticaretinin Erken Demir Çağı sonlarında zaten düzenli olarak yapılmakta olduğuna ve Doğu Ege yerleşimlerinin bu ticaretin paydaşı olduklarına kanıt oluşturmaktadır. Bu verilerin yanı sıra, Miletos kazıları doğrultusunda, Miletos ya da Güneydoğu

105 Dupont 1998; 2007; Sezgin 2012; Bîrzescu 2012; 2013.

106 Lawall 2011a, b; Sezgin 2012, 140, 301; Bîrzescu 2012, 201; Leidwanger et al. 2012, 396; Greene et al. 2013, 26.

107 Kerschner - Mommsen 2005.

108 Sakarya 2016, 65-66.

109 Fantalkin - Tal 2010.

110 Kotsonas et al. 2017.

111 Bîrzescu 2013, 204. 
Ege amphoralarının MÖ VIII. yüzyılın sonları VII. yüzyılın başlarından itibaren takip edilebildiği görülmektedir ${ }^{112}$. Güneydoğu Ege amphorası olarak tanıtılan, Miletos amporalarının standart form özelliklerini tekrar eden Kekova Batığı buluntusu amphoralar ${ }^{113}$ söz konusu amphora tipinin MÖ VII. yüzyılın ortalarında gemi kargolarında varlığını belgelemiştir. Kargosundaki sepet kulplu amphoralardan dolayı Kıbrıs kökenli bir gemi olarak tanıtılan Kekova Batığı, taşıdığı Güneydoğu Ege/Miletos ve Korinth amphoralarının da gösterdiği gibi, içerdiği ürünlerin kaynağı bakımından uluslararası kimliğe sahip bir ticari gemidir. Söz konusu veriler, Miletos ve çevresinde Erken Demir Çağı'n sonlarında ya da en geç MÖ VII. yüzyılın ilk yarısı içerisinde, form özellikleri ile standartlaşmış amphora üretimlerinin varlığına işaret etmektedir. Bu süreçte Kıyı Karia'da ticari amphora üretimi başlamış mıydı sorusuna cevap vermek henüz mümkün görünmese de, Miletos ile Karia arasında materyal kültürde görülen ortaklık ve etkileşim, özellikle de Mylasa civarındaki atölyelerin Miletos seramiği etkisinde üretim yaptığı göz önüne alındığında, evet olmalıdır.

Karia'da Miletos tipi amphora üretimi farklı şekillerde açıklanmak istenmiştir: Karia'da üretilen malların Miletos tipinde amphoralarla, Miletos öncülüğünde pazarlandığ $\left.\right|^{114}$ veya Miletos'un Karia'da kendisine ait amphora formunu ürettirmiş ya da üretilmesine izin vermiş olduğu ${ }^{115}$ tartışımıştır. Her durumda en temel sorunlar Dupont'un da vurguladığı gibi, Miletos tipi amphoraların ne kadar geniş bir coğrafyada üretildiği ve ihracın tek bir tip ile yapılıp yapılmadığıdır ${ }^{116}$. Form özelliklerinden yola çıkarak, Miletos üretimleri ile bölgenin diğer merkezlerinin üretimlerini ayırt edebilmek oldukça güç görünmektedir ${ }^{117}$.

Bir diğer soru, Miletos tipi amphoraların oldukça geniş bir coğrafyada üretilmesinin, Miletos ile ilişkili ticari etkinliklerde nasıl yorumlanması gerektiğidir. Akdeniz, Ege ve Karadeniz kıyılarında bulunmuş olan Miletos tipinde amphoraların buluntu merkezleri Dupont, Monachov, Seifert, Sezgin ve Bîrzescu'nun çalışmalarında listelenmiştir. Akdeniz ${ }^{118}$, Karadeniz ${ }^{119}$, Kuzey Ege ve Trakya ${ }^{120}$ bölgeleriyle ilgili diğer çalışmalar, Miletos tipi amphoraların bölgeler çerçevesinde dağııım haritalarının oluşmasında önemli katkılar sağlamıştır. Karadeniz kıyısı kolonilerinde bulunan amphoraların üretim merkez/bölgelerine göre yapılan istatistiksel değerlendirmelerde, Miletos tipinde olanların Khios, Lesbos ve Klazomenai üretimlerinden sonra geldiği görülmekte$\operatorname{dir}^{121}$. Sadece Miletos ve teritoryumunda değil, Karia'nın önemli bir bölümünde de Miletos tipinde amphoraların üretildiği dikkate alındığında, bunların denizaşırı yerleşimlerde temsil edilme oranının oldukça önemsizleşeceği sonucu ortaya çıkmaktadır. Eğer Miletos tipi amphoralarda, Miletos'tan Keramos Körfezi kıyısı, hatta Knidos bölgesi tarımsal ürünleri pazarlanıyor ise, Miletos ve Karia kıyısı yerleşimlerinin amphoralar ile taşınan tarımsal üretimlerinin Arkaik Dönem ticaretinde oldukça önemsiz bir paya sahip olduğu rahatlıkla söylenebilir. Şüphesiz bu yorum ticari değer oluşturan bölge ürünlerinin yerel üretim amphoralar ile taşınması durumunda geçerlidir. Burada Knidos topraklarını belki ayrı tutmak gerekir. Knidos Yarımadası verileri, Miletos tipinde amphoralar dışında, Samos-Miletos tipi amphoralar için de bölgenin olası üretim alanı olarak kabul edilebileceğine işaret etmektedir. Ayrıca Knidos ile Miletos ve çevresinin

112 Seifert 2004, 13; Naso 2005, 75.

113 Greene et al. 2013, fig. 3.

114 Dupont 1998, 175-176; 2007.

115 Sezgin 2012, 140.

116 Dupont 2007, 621.

117 Bîrzescu 2012, 130.

118 Waldbaum 2011; Sacchetti 2012; Klug 2013.

119 Bujskikh 2014a, b; Tolstikov et al. 2017.

120 Lozanov 2010; Tzochev 2010; Filis 2012a, b; 2013; Dupont - Skarlatidou 2012; Kotsonas et al. 2017.

121 Dupont 2007; Bîrzescu 2012, 201; Dupont - Skarlatidou 2012, 259 dn. 19. 
tarımsal üretimleri, Knidos'ta şarap ${ }^{122}$ Miletos çevresinde ise zeytinyağı ${ }^{123}$ olmak üzere farklılaşmaktadır. Koloni yerleşimlerinde zeytinyağı üretilen bölgelerin amphoralarının az bulunması, yeme içme alışkanlıklarındaki farklııklar ile bağlantılı görülmüştür. Kolonilerde şarabın tüm topluluklarca, zeytinyağının ise kolonistlerce kullanıldığı önerilmiştir ${ }^{124}$. Bu yorumun tarafı olmak, Miletos tipi amphoraların denizaşırı yerleşimlerde az bulunmasını anlamamızı kolaylaştırır ve dağııımlarının azlığı veya çokluğunu ticari ilişkilerin merkezine yerleştirmememiz gerektiği konusunda da kısmen ikna eder.

Karia kıyıları ve yakın geri bölgelerde üretilen zeytinyağının ve diğer tarımsal ürünlerin MÖ VII. yüzyıl içerisinde Akdeniz ticaretinde sınırlı da olsa belli bir yer edindiği ve Kıbrıs amphoraları ile taşınmış olabileceği, Karia ve Lykia kıyısında belgelenmiş olan Kıbrıs batıklarından dolayı daha önce önerilmişti ${ }^{125}$. Bölgede Erken Demir Çağı içlerinden itibaren önemli miktarlarda zeytinyağı üretildiği ve kırsal ekonominin temel unsurlarından birini oluşturduğu, son yılların arkeolojik verileri ile belgelenmiştir. Keramos kırsalında yürütülmekte olan kurtarma kazılarında MÖ VIII. ve VII. yüzyıllara tarihlenen mezarların kapağı olarak kullanılmış pres altıkları, zeytinyağının bölge ekonomisindeki önemini göstermektedir. Arkasından gelen dönemlere ait aynı bölgeden belgelenmiş çok sayıda işlik ${ }^{126}$, Leleg Yarımadası örnekleri ${ }^{127}$ ile birlikte, bölgenin üretim yoğunluğunu yansıtan arkeolojik verileri sağlamıştır. Söz konusu veriler, Keramos Körfezi kuzeyinde, en geç MÖ VIII. yüzyıldan itibaren ticari değere dönüşmüş zeytinyağı üretilmiş olduğuna işaret etmektedir. Arkaik Dönem içerisinde, bölge ve yakın bölge yerleşimlerinin ihtiyacını karşılamak için, Pabuçburnu Batığı'ndan da anlaşıldığı gibi, yerel gemilerin kıyı boyunca seyahat ettikleri anlaşılmaktadır. Miletoslu ve ilişkili Karialı tüccarların, muhtemelen en geç MÖ VII. yüzyıın başlarından itibaren, Ege ve Akdeniz ticaretinde Doğu Akdenizli tüccarlarla işbirliği içerisinde kurdukları ticari ilişkilerin sürekliliğini, Keramos ve Miletos arasında üretilen ürünlerin katkısı ile sağlamış oldukları ve bölge üretimlerinin Miletos kentinin ihtiyaçlarını karşılamak için de oldukça önemli olduğu, muhtemelen Pedasa için de benzer dinamiklerin geçerli olduğu söylenebilir.

\section{Sonuç}

Arkeolojik veriler, Leleg Yarımadası, Mandalya Körfezi ve çevresi topluluklarının, Ionia seramiklerini doğrudan veya taklit ederek kullandığını göstermektedir. Pedasa buluntusu amphoraların, Miletos ve çevresi yerleşimlerin amphoraları ile tipolojik ve kronolojik benzerlik göstermesi, Pedasa'yı Miletos merkezli materyal kültürün önemli ortaklarından/takipçilerinden biri yapmaktadır. Miletos tipi amphoraların yerleşimde ele geçmekte olan tüm amphoraların yaklaşık \%90 civarındaki kısmını oluşturması oldukça dikkat çekmekte, diğer taraftan ise bazı soruları da gündeme taşımaktadır. Bu amphoraların ne kadarı Miletos üretimi, ne kadarı Kıyı Karia üretimidir. Ön değerlendirmelere göre ve bantlı ve dalgalı çizgili örneklerin de işaret ettiği gibi, Pedasa'da Miletos üretimlerinin oldukça yoğun olduklarıdır. Ephesos Tetragonos Agorası'nda Miletos tipinde amphoralar tüm amphoraların yarısından fazlasını oluşturmaktadır ve yakın bölgelerarası ticari ilişkilerin tanımlanması ve yorumlanması bakımından önemlidir ${ }^{128}$. Pedasa verileri de, yakın bölgelerarası ticari ilişkilerin yorumlanmasına önemli katkılar sağlamaktadır. Miletos tipinde amphoraların Kıyı Karia'nın da amphora tipi olması ve bölge yerleşimlerinde yaygınlığı, daha çok bölgesel kullanıma hizmet ettiklerine, belki de Miletos vatandaşlarının ihtiyacının karşılanma-

122 Panagou 2016.

123 Dupont 1998, 175; Naso 2005, 83.

124 Dupont 1998, 143.

125 Özer 2017.

126 Kızıl 2010; Söğüt - Gider 2010.

127 Diler 2010; 2015.

128 Kerschner - Mommsen 2005. 
sında önemli olduğuna işaret etmektedir.

Bölge ve denizaşırı yerleşimlerin buluntusu amphoralardan çok sayıda örneğin kil analizinin yapılması, üretim alanlarının tarımsal ürünlerinin bölgesel ve denizaşırı ticaretteki etkisinin anlaşılabilmesi bakımından oldukça önemli sonuçların elde edilmesini sağlayacaktır. Kıyı Karia ve iç bölge topluluklarının Arkaik Dönem ticaretine ne ölçüde katkı sağladıkları ve yakın bölge ve denizaşırı kültürlerle kurulan ilişkilerin, toplulukların sosyo-ekonomik durumlarına etkisi, arkeolojik ve arkeometrik çalışmalar sonrasında çok daha iyi anlaşılabilecektir. Miletos'un tüm bu ilişkilerin sürekliliğindeki rolü, bölgedeki diğer kazı verileri çerçevesinde tekrar değerlendirilmelidir.

Attula 2005/06

Attula 2006a.

Attula 2006b

Bean - Cook 1955

Bîrzescu 2009

Bîrzescu 2012

Bîrzescu 2013

Bujskikh 2014a

Bujskikh 2014b

Cankardaş-Şenol et al. 2004

Carlson 2003

\section{BİBLIYOGRAFYA}

M. Akurgal, M. Kerschner, H. Mommsen - W. D. Niemeier, Töpferzentren der Ostägäis. Archäometrische und archäologische Untersuchungen zur mykenischen, geometrischen und archaischen Keramik aus Fundorten in Westkleinasien. Ergänzungshefte zu den Jahreshefte des Österreichischen Archäologischen Institutes in Wien. Heft 3. Wien 2002.

R. Attula, "Transportamphoren von der knidischen Halbinsel: Das Potential von Amphorenstempeln für die Erforschung der knidischen Töpfereigeschichte". Skyllis: Zeitschrift für Unterwasserarchäologie 7 (2005/2006) 40-48.

R. Attula, "Archaic Greek Plates from the Apollo Sanctuary at Emecik, Knidia. Results and Questions Concerning Dorian Pottery Production". Eds. A. Villing - U. Schlotzhauer, Naukratis: Greek Diversity in Egypt. Studies on East Greek Pottery and Exchange in the Eastern Mediterranean. London (2006) 85-92.

R. Attula, "Ostdorische Keramik". Ed. D. Berges, Knidos, Beiträge zur Geschichte der archaischen Stadt. Mainz am Rhein (2006) 114-136.

G. E. Bean - J. Cook, "The Halicarnassus Peninsula". BSA: The Annual of the British School at Athens 50 (1955) 85-171.

I. Bîrzescu, "Funde aus Milet, XXI. Drei Typen archaischer Reifenamphoren aus Milet". AA: Archäologischer Anzeiger (2009/1) 121-134.

I. Bîrzescu, Histria XV. Die archaischen und frühklassischen Transportamphoren. Bucarest 2012.

I. Bîrzescu, "Transport Amphoras of the Second Half of the 7th - Beginning of the 6th Cent. BC in Histria". Eds. L. Buzoianu, P. Dupont - V. Lungu, Patabs. III. Production and trade of amphorae in the Black Sea = Production et commerce amphoriques en Mer Noire. Actes de la Table Ronde internationale de Constanţa, 6-10 octobre 2009. Constanţa (2013) 201-212. A. Bujskikh, "Amphorae and Table Wares". Ed. V. N. Zin'ko, Tyritake. Sector XXVI. Vol. II. Bosporan Studies. Suppl. 11. Simferopol-Kerch. (2014) 87-214.

A. Bujskikh, "Amphorae of the end of 7th - the early 5tn century BC of Borysthenes". Archaeologiya i davnya istoriya Ukrainy. 1(12) (2014) 88-100.

G. Cankardeş-Şenol, A. K. Şenol - E. Doğer, "Amphora Production in the Rhodian Peraea in the Hellenistic Period". Eds. J. Eiring - J. Lund, Transport Amphorae and Trade in the Eastern Mediterranean. Acts of the International Colloquium at the Danish Institute at Athens, Sept. 26-29, 2002. Monographs of the Danish Institute at Athens, Volume 5. Danish Institute at Athens (2004) 353-359.

D. N. Carlson, "The Classical Greek Shipwreck at Tektaş Burnu, Turkey". 
Carlson - Lawall 2005/06

Carstens 2008

Cook 1998

Cook 1999

Diler 2010

Diler 2011

Diler 2015

Doğer 1994

Doğer - Şenol 1996

Donati 2013

Dupont 1983

Dupont 1986

Dupont 1998

Dupont 2007

Dupont 2010

Dupont - Skarlatidou 2012

Empereur - Picon 1986

Fantalkin - Tal 2010
AJA 1074 (2003) 581-600.

D. N. Carlson - M. L. Lawall, "Towards a Typology of Erythraian Amphoras". Skyllis : Zeitschrift für Unterwasserarchäologie 7 (2005/2006) 32-39.

A. M. Carstens, "Tombs of the Halikarnassos Peninsula-The Late Bronze and Early Iron Age". Ed. P. Pedersen, Halicarnassian Studies V. Odense (2008) 52-118.

R. M. Cook, "The Wild Goat style". R. M. Cook - P. Dupont, East Greek Pottery. London-New York (1998) 32-70.

R. M. Cook, "A List of Carian Orientalizing Pottery". OxfJA 18 (1999) 79-93. A. Diler, "Olive Oil and Wine Production of the Halikarnassos Peninsula in Karia”. Eds. Ü. Aydınoğlu - A. K. Şenol, Antik Çağda Anadolu'da Zeytinyağı ve Şarap Üretimi: Sempozyum Bildirileri, 06-08 Kasım 2008, Mersin. İstanbul (2010) 135-174.

A. Diler, "Pedasa-2008/2009". KST 32 (2011) 324-341.

A. Diler, "Agricultural Land Use in Lelegian Termera: Change in Settlement Model in Agricultural Landscape". Eds. A. Diler, A. K. Şenol - Ü. Aydınoğlu, Antikçağ’da Doğu Akdeniz'de Zeytinyağı ve Şarap Üretimi. Uluslararası Sempozyum Bildirileri, 17-19 Kasım 2011 Urla-Izmir. İzmir (2015) 1-30.

E. Doğer, "Rodoslu Çömlekçi Hieroteles". ADerg II (1994) 195-218.

E. Doğer - A. K. Şenol, "Rhodos Peraias'nda İki Yeni Amphora Atölyesi". ADerg IV (1996) 59-73.

L. Donati, "Agorà. The fountains and the archaic period". Eds. D. Baldoni, F. Berti - M. Giuman, lasos e il suo territorio; atti del convegno internazionale per i cinquanta anni della Missione Archeologica Italiana, İstanbul, 26-28 Febbraio 2011. Roma (2013) 21-36.

P. Dupont, "Classification et détermination de provenance des céramiques grecques oriantales archaïques d'Istros, Rapport Préliminaire". Dacia 27 (1983) 19-43.

P. Dupont "Naturwissenschaftlische Bestimmung der archaischen Keramik Milets". Hrsg. W. Müller-Wiener, Milet 1899-1980, Ergebnisse, Probleme und Perspektiven einer Ausgrabung. Kolloquium Franfurt am Main 1980. Istanbuler Mitteilungen Beiheft 31. Tübingen (1986) 57-71.

P. Dupont, "Archaic East Greek trade amphoras". Eds. R. M. Cook - P. Dupont, East Greek Pottery. London-New York (1998)142-191.

P. Dupont, "Diffusion des amphores commerciales de type milésien dans le Pont archaïque". Hrsg. J. Cobet, V. von Graeve, W.-D. Niemeier - K. Zimmermann, Frühes Ionien eine Bestandsaufnahme, Panionion-Symposion Güzelçamlı, 26. September - 1. Oktober 1999, Milesische Forschungen 5. Mainz am Rhein (2007) 621-630.

P. Dupont, "Erythraea: 1. Les amphores "samiennes" et "protothasiennes" de Zeest: la piste nord-ionienne ?". Eds. D. Kassab Tezgör - N. Inaishvili, Patabs I, production and trade of amphorae in the Black Sea. Actes de la Table Ronde internationale de Batoumi et Trabzon, 27 - 29 avril 2006. Varia Anatolica 21. Paris (2010) 39-43.

P. Dupont - E. Skarlatidou, "Archaic Transport Amphoras from the First Necropolis of Clazomenian Abdera". Eds. M. Tiverios, V. MisailidouDespotidou, E. Manakidou - A. Arvanitaki, Archaic pottery of the Northern Aegean and its periphery (700-480 BC). Proceedings of the Archaeological Meeting Thessaloniki, 19-22 May 2011. Thessaloniki (2012) 253-264.

J. Empereur - M. Picon, "A la recherche des fours d'amphores". BCH: Bulletin de correspondance hellénique, Supplément XIII (1986) 103-126.

A. Fantalkin - O. Tal, "Reassessing the Date of the Beginning of the Gray Series of Transport Amphorae from Lesbos". BABesch: Bulletin antieke 
Fazlıoğlu 2007

Fazlıŏlu 2009

Filis 2012a

Filis 2012b

Filis 2013

Furtwängler - Kienast 1989

Grace 1971

Greene - Lawall 2005/06

Greene et al. 2008

Greene et al. 2013

Hein et al. 2008

Ibba 2004

Johnston 1990

Kalaitzoglou 2008

Kantzia 1994

Kerschner 2017 beschaving. Annual Papers on Classical Archaeology 85 (2010) 1-12.

i. Fazlıoğlu, "Relations between Caria and Ionia on the Basis of Orientalizing Pottery". Hrsg. J. Cobet, V. von Graeve, W.-D. Niemeier - K. Zimmermann, Frühes lonien eine Bestandsaufnahme. Panionion-Symposion Güzelçamlı, 26. September - 1. Oktober 1999. Milesische Forschungen 5. Mainz am Rhein (2007) 253-261.

i. Fazlıoğlu, "Damlıboğaz Finds: Inland Carian Archaic Pottery and Related Regions". Hrsg. F. Rumscheid, Die Karer und die Anderen. Internationales Kolloquium an der Freien Universität Berlin 13. bis 15. October 2005. Bonn (2009) 463-477.

K. Filis, "Trade amphorae from Karabournaki". Eds. E. Kefalidou - D. Tsiafaki, Kerameos Paides: studies offered to Professor Michalis Tiverios by his students. Thessaloniki (2012) 309-320.

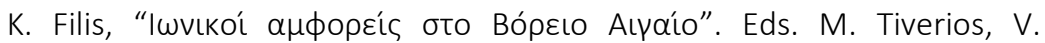
Misailidou-Despotidou, E. Manakidou - A. Arvanitaki, Archaic pottery of the Northern Aegean and its periphery (700-480 BC). Proceedings of the Archaeological Meeting Thessaloniki, 19-22 May 2011. Thessaloniki (2012) 265-280.

K. Fillis, "Transport Amphorae from Akanthos". Eds. L. Buzoianu, P. Dupont - V. Lungu, Patabs III. Production and trade of amphorae in the Black Sea= Production et commerce amphoriques en Mer Noir. Actes de la Table Ronde internationale de Constanţa, 6-10 octobre 2009. Constanţa (2013) 67-87.

A. E. Furtwängler - H. J. Kienast, Der Nordbau im Heraion von Samos, Samos Band III. Bonn 1989.

V. R. Grace, "Samian amphoras". Hesperia: Journal of the American School of Classical Studies at Athens 40 (1971) 52-95.

E. S. Greene - M. L. Lawall, "Amphora Capacities in Early Monetary Asia Minor: The Pabuç Burnu Shipwreck". Skyllis: Zeitschrift für Unterwasserarchäologie 7 (2005/2006) 17-23.

E. S. Greene, M. L. Lawall - M. E. Polzer, "Inconspicuous Consumption: The Sixth-Century B.C.E. Shipwreck at Pabuç Burnu, Turkey". AJA 112 (2008) 685-711.

E. Greene, J. Leidwanger - H. Özdaş, "Expanding Contact and Collapsing Distances in Early Cypro-Archaic Trade: Three Case Studies of Shipwrecks off the Turkish Coast". Eds. M. L. Lawall - J. Lund, The Transport Amphorae and Trade of Cyprus. Aarhus (2013) 22-34.

A. Hein, V. Georgopoulou, E. Nodarou - V. Kilikoglu, "Koan amphorae from Halasarna-investigations in a Hellenistic amphora production centre". Journal of Archaeological Science 35 (2008) 1049-1061.

M. A. Ibba, "La fontana "arcaica" dell'agora di lasos e suoi Materiali". Iasos tra VI e IV sec. a.C. Miscellanea storico-archeologica. Ferrara (2004) 73-99.

A. W. Johnston, "Aegina. Aphaia-Tempel. XIII. The storage amphorae". AA (1990) 37-64.

G. Kalaitzoglou, Assesos. Ein geschlossener Befund südionischer Keramik aus dem Heiligtum der Athena Assesia. Milesische Forschungen 6. Mainz am Rhein 2008.

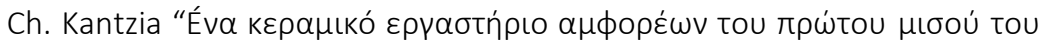

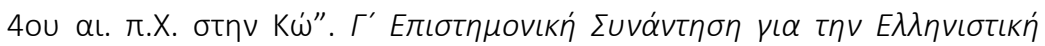

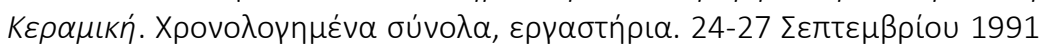

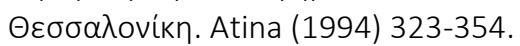

M. Kerschner, "East Greek pottery workshops in the seventh century BC: tracing regional styles". Eds. X. Charalambidou - C. Morgan, Interpreting the Seventh Century BC Tradition and Innovation. Oxford (2017) 100-113. 
Kerschner - Mommsen 2005

KızII 2010

Kleiner et al. 1967

Klug 2013

Kotsonas et al. 2017

Lawall 2011a

Lawall 2011b

Leidwanger et al. 2012

Lozanov 2010

Lüdorf 2007

Mănucu-Adameşteanu 2008

Mommsen et al. 2006

Monachov 2003

Naso 2005

Özer 2015a
M. Kerschner - H. Mommsen, "Transportamphoren milesischen Typus in Ephesos: Archöometrische und archäologische Untersuchungen zum Handel im archaischen lonien". Hrsg., B. Brandt, V. Gassner - S. Ladstätter. Synergia: Festschrift für Friedrich Krinzinger. Wien (2005) 119-130.

A. Kızıl, "Keramos'un Kuzeyinde Yapılan Yüzey Araştırmalarında Tespit Edilen Zeytinyağı İ̧likleri". Eds. Ü. Aydınoğlu - A. K. Şenol, Antik Çağda Anadolu'da Zeytinyağı ve Şarap Üretimi: Sempozyum Bildirileri, 06-08 Kasım 2008, Mersin. İstanbul (2010) 259-275.

G. Kleiner, P. Hommel - W. Müller-Wiener, Panionion und Melie. (Jdl 23). Ergänzungsheft. Berlin 1967.

R. D. Klug, Griechische Transportamphoren im regionalen und überregionalen Handel: Untersuchungen in griechischen und nicht-griechischen Kontexten in Unteritalien und Sizilien vom 8. bis zum 5. Jh. v. Chr. RahdenWestfalen (2013).

A. Kotsonas, E. Kiriatzi, X. Charalambidou, M. Roumpou, N. Suzanne Müller - M. Bessios, "Transport Amphorae from Methone: An Interdisciplinary Study of Production and Trade ca. 700 BCE". Eds. J. S. Clay - I. Malkin - Y. Z. Tzifopoulos, Panhellenes at Methone, Graphê in Late Geometric and Protoarchaic Methone, Macedonia (ca. 700 BCE). Berlin-Boston (2017) 9-19. M. L. Lawall, "Socio-Economic Conditions and the Contents of Amphorae". Eds. C. Tzochev, T. Stoyanov - A. Bozkova, Patabs II: Production and Trade of Amphorae in the Black Sea. Acts of the International Round Table held in Kiten, Nessebar and Sredetz, September 26-30, 2007. Sofia (2011) 23-33. M. L. Lawall, "Greek Amphorae in the Archaeological Record". Eds. M. L. Lawall - J. Lund, Pottery in the Archaeological Record: Greece and Beyond. Gönsta Enbom Monographs 1. Aarhus (2011) 38-50.

J. Leidwanger, H. Özdaş - E. Greene, "Sourcing the Cargos of three archaic Shipwrecks: Kekova Adası, Kepçe Burnu and Çaycağız Koyu". ArkST 27 (2012) 393-409.

I. Lozanov, "On the import amphorae in Thrace $\left(6^{\text {th }}-3^{\text {rd }}\right.$ centuries B.C.): Reflections on Some Recent discoveries in the Middle Hebros Valley". Eds.

D. Kassab Tezgör - N. Inaishvili, Patabs I, production and trade of amphorae in the Black Sea. Actes de la Table Ronde internationale de Batoumi et Trabzon, 27 - 29 avril 2006. Varia Anatolica 21. Paris (2010) 85-96.

G. Lüdorf, "Die Rastersurveys an Çatallar-und Belen Kuyu Tepe". H. Lohmann, "Forschungen und Ausgrabungen in der Mykale 2001-2006". IstMitt 57 (2007) 168-174. 59-178.

M. Mănucu-Adameşteanu, Orgame, Cercetări arheologice II, Ceramica Arhaică. Bucureşti 2008.

H. Mommsen, A. Schwedt - R. Attula "Chemische Klassifizierung von 137 Keramikproben aus den Grabung in Emecik und des Töphereistandorts Reşadiye durch Neutronenaktivierungsanalyse". Ed. D. Berges, Knidos, Beiträge zur Geschichte der archaischen Stadt. Mainz am Rhein (2006) 199-204.

S. J. Monachov, Grečeskie amfory v Pričernomor'e :tipologija amfor veduščich centrov-èksporterov tovarov v keramičeskoj tare. Moskva 2003. A. Naso, "Funde aus Milet, XIX. Anfore commerciali arcaiche a Mileto. Rapporto preliminare". AA (2005/2) 73-84.

B. Özer, "Archaic Pottery of Coastal Caria: Finds from a Cremation Burial at Bybassos". Eds. R. G. Gürtekin-Demir, H. Cevizoğlu, Y. Polat - G. Polat, Keramos, Ceramics: A Cultural Approach. Proceedings of the First International Conference at Ege University, İzmir, May 9-13, 2011. Ankara 
Özer 2015b

Özer 2017

Özer 2018a

Özer 2018b

Panagou 2016

Radt 1970

Ruban 1991

Sacchetti 2012

Sakarya 2016

Schattner 2007

Schlotzhauer - Villing 2006

Seifert - Yalçın 1994

Seifert 2000

Seifert 2004

Sezgin 2012

Sezgin 2017

Söğüt - Gider 2010

Şenol 2003

Şenol - Şenol 2010

Tolstikov et al. 2017

Tuna et al. 2009
(2015) 197-207.

B. Özer. "Kıуı Karia Arkaik Seramiği: Yerel Formlar, Kültürel Sınırlar". Eds. E. Okan - C. Atilla, Prof. Dr. Ömer Özyiğit'e Armağan. İstanbul (2015) 331347.

B. Özer, "Pedasa Athena Kutsal Alanı Arkaik Dönem Kıbrıs Mortarları ve Bölgeler Arası Ticari İlişkilerdeki Rolü". Adalya XX (2017) 41-67.

B. Özer, "Kıуı Karia Arkaik Seramiği: Karia Kaseleri ve Denizaşırı Dağılımları". Arkeoloji ve Sanat 156 (baskıda).

B. Özer, "Orientalizing Style Pottery From Pedasa: Ionian Imports". Karia Archaia. 2017 (baskıda).

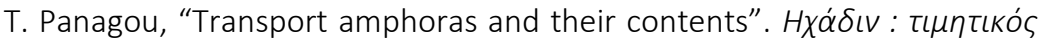

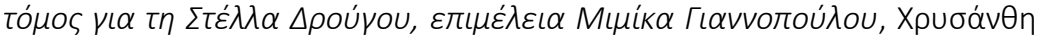

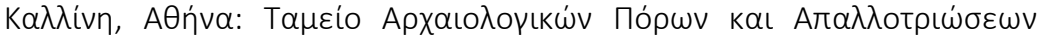
(2016) 313-334.

W. Radt, Siedlungen und Bauten auf der Halbinsel von Halikarnassos: unter besonderer Berücksichtigung der archaischen Epoche. Istanbuler Mitteilungen Beiheft 3. Tübingen 1970.

V. V. Ruban, "An attempt of classification of so-called Milesian amphorae from the lower Bug area". SovA (1991/2) 182-195.

F. Sacchetti, Les amphores grecques dans le nord de l'Italie: échanges commerciaux entre les Apennins et les Alpes aux époques archaïque et classique. Paris 2012

i. Sakarya, Trade Relations of Ancient Burgaz from Archaic to mid of $4^{\text {th }}$ Centuries: The Amphorae Evidence within the Domestic Contexts. Yayınlanmamış Doktora Tezi, Orta Doğu Teknik Üniversitesi. Ankara 2016.

T. G. Schattner, Die Fundkeramik vom 8. bis zum 4. Jahrhundert v. Chr. Didyma Teil 3. Ergebnisse der Ausgrabungen und Untersuchungen seit dem Jahre 1962. Band 4. Mainz am Rhein 2007.

U. Schlotzhauer - A. Villing, "East Greek Pottery from Naukratis: The Current State of Research". Eds. A. Villing - U. Schlotzhauer, Naukratis: Greek Diversity in Egypt. Studies on East Greek Pottery and Exchange in the Eastern Mediterranean. London (2006) 53-68.

M. Seifert - Ü. Yalçın, "Milet'te Arkeometrik Araştırmalar". ArkST X (Ankara 1994) 15-38.

M. Seifert, "Archaische Vorrats- und Transportamphoren in Milet". Münstersche Beiträge zur antiken Handelsgeschichte 19/2 (2000) 1-39.

M. Seifert, Herkunftsbestimmung archaischer Keramik am Beispiel von Amphoren aus Milet. BAR International Series 1233. Oxford (2004).

Y. Sezgin, Arkaik Dönem Ionia Üretimi Ticari Amphoralar. İstanbul 2012.

Y. Sezgin, "Arkaik Dönemde Teos'ta Ticari Amphora Üretimi: Sorunlar ve Gözlemler". Anadolu 43 (2017) 15-39.

B. Söğüt - Z. Gider, "Belentepe Hellenistik Dönem Zeytinyağı Atölyeleri". Eds. Ü. Aydınoğlu - A. Kaan Şenol, Antik Çağda Anadolu'da Zeytinyağı ve Şarap Üretimi: Sempozyum Bildirileri, 06-08 Kasım 2008, Mersin. İstanbul (2010) 241-257.

A. K. Şenol, Marmaris Müzesi ticarî amphoraları. Ankara 2003.

A. K. Şenol - G. Cankardaş-Şenol, "Bybassos Yüzey Araştırması, Keramik Çalışmaları". Kaynak: http://www.poliskultur.de.

V. P. Tolstikov, N. S. Astashova, G. A. Lomtadze, O. Yu. Samar - O. V. Tugusheva, The Earliest Panticapaeum. From an Apoikia to a City. Moscow 2017

N. Tuna, N. Atıcı, I. Sakarya - E. Koparal, "The Preliminary Results of Burgaz Excavations within the Context of Locating Old Knidos". Hrsg. F. 
Tuchelt et al. 1996

Tzochev 2010

Villing - Mommsen 2017

Villing - Schlotzhauer 2006

Voigtländer 2004

Waldbaum 2011

Walter-Karydi 1973

Wascheck 2008

Zadnikov 2006
Rumscheid, Die Karer und die Anderen. Internationales Kolloquium an der Freien Universität Berlin 13. bis 15. October 2005. Bonn (2009) 517-531. K. Tuchelt, P. Schneider, T. G. Schattner - H. R. Baldus, Ein Kultbezirk an der Heiligen Straße von Milet nach Didyma, Didyma Dritter Teil; Ergebnisse der Ausgrabungen und Untersuchungen seit dem Jahre 1962 Bd. 1. Mainz am Rein 1996.

Ch. Tzochev, "Between the Black Sea and the Aegean: the diffusion of Greek trade amphorae in southern Thrace ?". Eds. D. Kassab Tezgör - N. Inaishvili, Patabs I, production and trade of amphorae in the Black Sea. Actes de la Table Ronde internationale de Batoumi et Trabzon, 27 - 29 avril 2006. Varia Anatolica 21. Paris (2010) 97-101.

A. Villing - H. Mommsen, "Rhodes and Kos: East Dorian Pottery Production of the Archaic Period". BSA: The Annual of the British School at Athens 112 (2017) 99-154.

A. Villing - U. Schlotzhauer, Naukratis: Greek Diversity in Egypt. Studies on East Greek Pottery and Exchange in the Eastern Mediterranean. London 2006.

W. Voigtländer, Teichiussa, Näherung und Wirklichkeit. Rahden-Westfalen 2004.

J. C. Waldbaum, "Greek Pottery". Eds. L. E. Stager, D. M. Master - J. Schloen, Final Reports of the Leon Levy expedition to Ashkelon. Ashkelon 3, The Seventh century B.C. Eisenbrauns (2011) 127-328.

E. Walter-Karydi, Samische Gefässe des 6. Jahrhunderts v. Chr., Samos VI/ 1 Bonn 1973.

F. Wascheck, "Fikellura-Amphoren und -Amphoriskoi von Milet, Ein Gefäßlager am Kalabaktepe". AA (2008/2) 47-81.

C. A. Zadnikov, "Мілетські тарні амфори в лісостеповому Дніпровському Лівобережжі, (за матеріалами зольників № 5 та 28 Західного укріплення Більского городища)". Більске городище та його округа (до 100- річчя початку польових досліджень). Київ (2006) 105-115. 